\title{
DISTRIBUSI KUAT GESER BATUAN PADA FORMASI MUARAENIM YANG MENGANDUNG BATUBARA DI KECAMATAN MERAPI BARAT, KABUPATEN LAHAT, PROVINSI SUMATERA SELATAN
}

\section{ROCK'S SHEAR STRENGTH DISTRIBUTION ON MUARAENIM FORMATION WHICH CONTAINS COAL AT MERAPI BARAT, LAHAT DISTRICT, SUMATRA SELATAN PROVINCE}

\author{
Nur Hamid'1, Hendarmawan², Dicky Muslim², Budi Nurani Ruchjana ${ }^{3}$ \\ ${ }^{1}$ Mahasiswa Pasca Sarjana Fakultas Teknik Geologi, Universitas Padjadjaran \\ ${ }^{2}$ Dosen Fakultas Teknik Geologi, Universitas Padjadjaran \\ ${ }^{3}$ Dosen Jurusan Statistik, Fakultas MIPA, Universitas Padjadjaran \\ nurhamid361rl@gmail.com
}

\begin{abstract}
ABSTRAK
Masalah kemantapan lereng sering ditemukan dalam operasi penambangan terutama pada dinding penggalian tambangnya. Kegiatan produksi akan terganggu apabila lereng-lereng yang terbentuk sebagai akibat dari proses penambangan tidak stabil. Suatu tambang terbuka belum tentu memiliki besar sudut kemiringan lereng yang sama, hal ini diantaranya akibat dari kuat geser batuan (т) yang merupakan indeks kualitas batuan, semakin kecil kuat geser batuan maka semakin lemah kekuatan batuan dalam menyangga beban dan akan menjadi bidang lemah yang mudah longsor. Dalam penelitian ini digunakan metode pemetaan geologi dan analisis gama ray dari 43 lubang bor. Metode Kriging digunakan untuk mengetahui distribusi kuat geser batuan di daerah penelitian. Hasil analisis metode Kriging memperlihatkan distribusi kuat geser batuan yang mempunyai nilai rendah yaitu $200 \mathrm{ton} / \mathrm{m}^{2}$ mengarah ke selatan semakin menyempit dan secara vertikal distribusinya semakin dalam semakin berkurang.
\end{abstract}

Kata kunci: Tambang terbuka, longsor, kuat geser batuan, lereng, kriging

\section{ABSTRACT}

Slope stability issues are found in mining process especially in open pit wall. Production process will disturbed by unstable slopes which created during mining process. An open pit mine may has different slope stabilites. The shear strength of rock (Ø) is an index of rock's quality. Rock's strength value will be weaker as the decline in the value of rock strength and this situation could cause soil slides. This research was conducted using geology mapping and gama ray method analysis within 43 drill holes. Kriging method was used to find out the shear strength of rock $(\varnothing)$ distribution in research area. Kriging's analysis result shows that the shear strength of rock $(\varnothing)$ distribution which has a low value $\left(200 t o n / \mathrm{m}^{2}\right)$ will increase if it heads to South and vertically the value's distribution will decrease if it goes deeper into the subsurface.

Keywords: Open pit mine, landslide, rocks strength, slope, kriging

\section{PENDAHULUAN}

Indonesia adalah negara yang kaya dengan sumber daya alam, khususnya bahan tambang. Menurut data neraca sumber daya batubara tahun 2015, sumber daya batubara Indonesia mencapai 126 milyar ton, sedangkan cadangan diperkirakan berjumlah 28 milyar ton (Anonim, 2016), yang tersebar di seluruh Indonesia.

Longsor dapat terjadi pada hampir setiap kasus lereng alami atau lereng buatan 
secara pelan atau tiba-tiba dengan atau tanpa adanya tanda-tanda sebelumnya. Penyebab utama terjadinya keruntuhan lereng adalah meningkatnya tegangan geser, menurunnya kuat geser pada bidang longsor atau keduanya secara simultan (Pangemanan, dkk., 2014).

Batuan mempunyai sifat-sifat fisik dan mekanik asli tertentu, yang terdiri dari sudut geser dalam ( $\varnothing$ ), gaya kohesi (C) dan bobot isi $(\gamma)$. Sifat fisik dan mekanik batuan menentukan kekuatan batuan yang mempengaruhi kemantapan lereng. Batuan yang mempunyai porositas besar akan banyak menyerap air, dengan demikian bobot isinya menjadi lebih besar, sehingga memperkecil kemantapan lereng. Adanya air dalam batuan juga akan menimbulkan tekanan air pori yang memperkecil kuat geser batuan. Batuan yang mempunyai kuat geser kecil akan lebih mudah longsor. (Maulana, 2012).

Kestabilan lereng penambangan ditentukan oleh parameter geoteknik, antara lain: sifat fisik \& mekanik batuan, tinggi muka air tanah, getaran peledakan/gempa bumi, ground pressure alat-alat berat, struktur massa batuan, dan sebagainya. Akibat adanya ketidakpastian nilai parameter geoteknik yang digunakan dalam disain lereng tersebut menyebabkan lereng menjadi tidak stabil, sehingga diperlukan verifikasi terhadap parameter-parameter tersebut. (Aziz, dkk., 2011).

Analisis kestabilan lereng dilakukan untuk menentukan faktor aman dari bidang longsor yang potensial, yaitu dengan menghitung besarnya kekuatan geser untuk mempertahankan kestabilan lereng dan menghitung kekuatan geser yang menyebabkan kelongsoran kemudian keduanya dibandingkan, dari perbandingan yang ada didapat nilai Faktor Keamanan yang merupakan nilai kestabilan lereng yang dinyatakan dalam angka (Pangemanan, dkk., 2014).

Tulisan ini bertujuan untuk mengetahui sebaran kuat geser batuan yang berguna dalam menghitung kestabilan lereng pada tahap penambangan.

\section{Geologi Dan Keteknikan}

Formasi Muaraenim atau Formasi Palembang Tengah berumur Miosen Akhir hingga Pliosen Awal. Formasi ini secara umum ditandai dengan berkembangnya batubara. Formasi ini disusun oleh perselingan batulempung, batulanau, batupasir tufaan dan lapisan batubara. Formasi ini menunjukkan sekuen pengendapan pengkasaran ke atas dengan lingkungan pengendapan laut dangkal hingga darat. Bagian bawah formasi ini tersusun oleh batulempung kecoklatan, batupasir lempungan dan batupasir tufaan serta lapisan batubara. Bagian atas formasi ini disusun oleh perselingan batulempung kehijauan, batupasir, lapisan batubara dan endapan vulkanik. Fosil kayu dan foraminifera air tawar banyak dijumpai pada formasi ini (Jackson, 1961 dalam Koesoemadinata, et al., 1976).

Penyebaran batuan di suatu daerah ada diantaranya berkaitan dengan lingkungan pengendapan dan formasi batuan-batuan pada daerah tersebut. Selley (1988) mengatakan bahwa lingkungan pengendapan adalah bagian dari permukaan bumi yang mengalami proses fisik, kimia dan biologi berbeda dengan daerah yang berbatasan dengannya. Sedangkan menurut Boggs (2006) lingkungan pengendapan adalah karakteristik dari suatu tatanan geomorfik tempat proses fisik, kimia dan biologi berlangsung yang menghasilkan suatu jenis endapan sedimen tertentu. Dari hal tersebut di atas dapat diketahui penyebaran suatu batuan pada daerah tempat lingkungan pengendapan tersebut berada.

Batuan mempunyai sifat-sifat fisik dan mekanik asli tertentu, seperti sudut geser dalam ( $\varnothing)$, kohesi (c) dan bobot isi yang sangat berperan dalam menentukan daya dukung batuan yang mempengaruhi kemantapan lereng. 


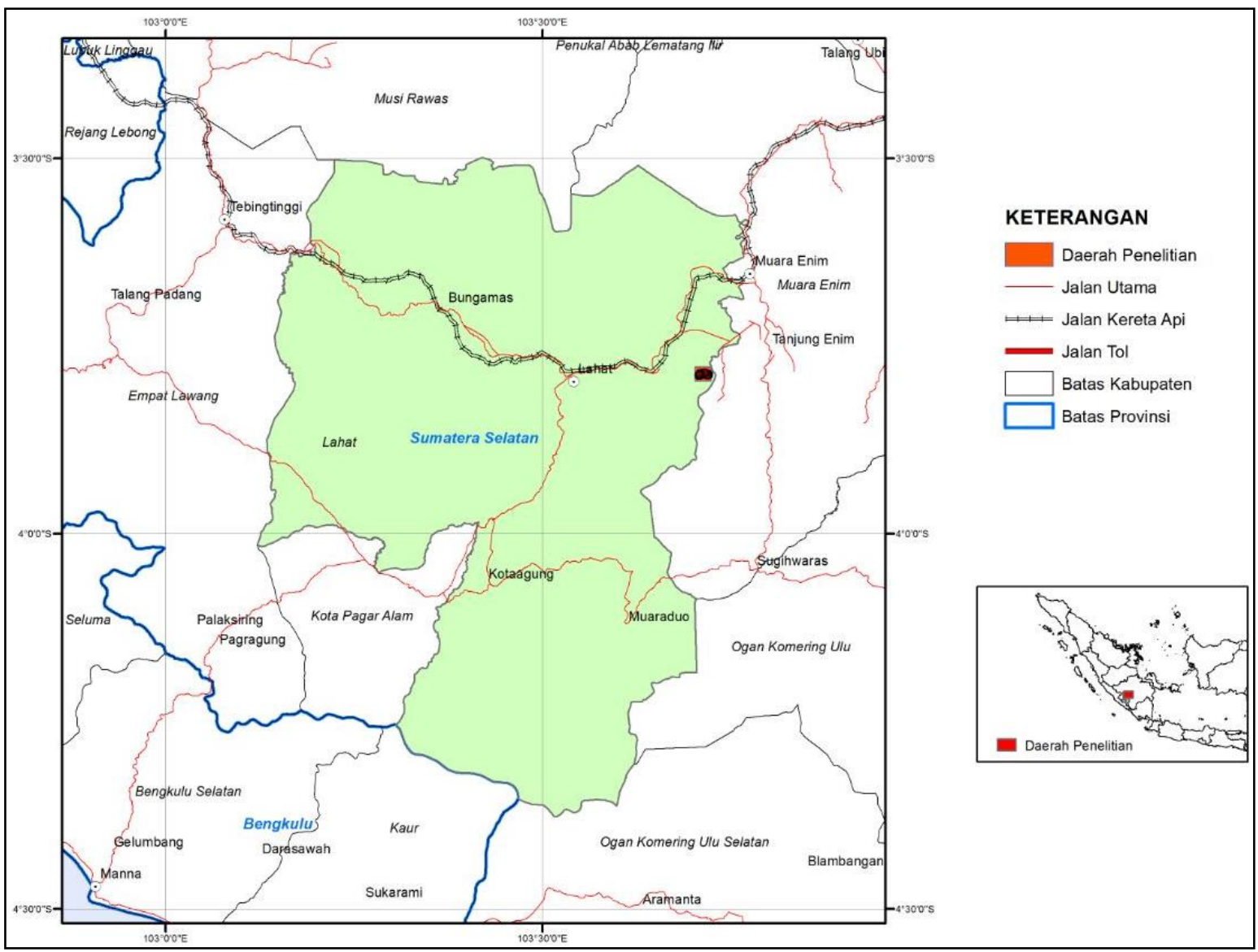

Gambar 1. Lokasi Penelitian

Batuan yang mempunyai porositas besar akan banyak menyerap air. Dengan demikian bobot isinya menjadi lebih besar, sehingga memperkecil kemantapan lereng. Adanya air dalam batuan juga akan menimbulkan tekanan air pori yang memperkecil kuat geser batuan. Batuan yang mempunyai kuat geser kecil akan lebih mudah longsor (Maulana, 2012).

Untuk mengetahui penyebaran zona batuan yang mempunyai kuat geser rendah dan merupakan zona lemah batuan di daerah tambang digunakan Metoda Kriging. Kriging merupakan analisis data geostatistika yang digunakan untuk mengestimasi besarnya nilai yang mewakili suatu titik yang tidak tersampel berdasarkan titik-titik tersampel yang berada di sekitarnya dengan mempertimbangkan korelasi spasial yang ada dalam data tersebut. Kriging merupakan suatu metode interpolasi yang menghasilkan prediksi atau estimasi tak bias dan memiliki kesalahan minimum. Indikator kriging adalah suatu metode estimasi yang tidak membutuhkan asumsi normalitas data dan juga dapat digunakan untuk mengatasi data yang mempunyai outlier yang signifikan. Indikator kriging yang dijalankan berdasarkan prinsip dari ordinary kriging disebut juga dengan ordinary indicator kriging (Aldila, 2013).

Suprayitno (2005) mengatakan bahwa metode kriging merupakan metode khusus dalam moving average terbobot (weighted moving average) yang meminimalkan variansi dari hasil estimasi. Kriging adalah metode estimasi BLUE (Best Linier Unbiased Estimator) dari nilai-nilai titik atau rata-rata blok. Metode estimasi ini mempertimbangkan faktor-faktor yang mempengaruhi akurasi estimasi, yaitu banyaknya sampel, posisi sampel, jarak antar sampel dengan titik yang akan diestimasi, kontinuitas spasial dari variabel-variabel yang terlibat, dan lain- 
lain. Dengan kata lain metode kriging digunakan untuk mengestimasi besarnya nilai karakteristik dari estimator (z) pada titik tidak tersampel berdasarkan informasi dari titik-titik tersampel yang berada disekitarnya.

\section{METODOLOGI}

Penelitian ini didasarkan pada data dari pemetaan geologi lapangan dan pengeboran dari 45 lubang bor terdiri dari open hole, full coring dan tuch coring dengan kedalaman antara 40 meter s.d. 100 meter, lokasi titik lubang bor terlihat pada gambar 1. Data dari pengeboran adalah berupa core dari 3 lubang full coring yaitu lubang GT-01, GT-02 dan GT03, sampel dipililih yang dapat mewakili batuan yang ada di daerah penelitian yang kemudian dikirim ke laboratorium untuk mengetahui harga/nilai sifat fisik dan mekaniknya. Korelasi batuan antar lubang bor didasarkan pada data gamma ray dari pembacaan geophysical logging.

Kuat geser batuan adalah gaya perlawanan yang dilakukan oleh butir batuan terhadap desakan atau tarikan. Bila tanah mengalami pembebanan akan ditahan oleh:

- Kohesi tanah yang tergantung pada jenis tanah dan kepadatannya

- Gesekan antar butir-butir tanah

Untuk menghitung kuat geser ini digunakan rumus dari Coulomb, 1910 (dalam Sagala P.S.S, 2014) yang di definisikan:

dengan:

$$
\tau=c+\sigma \operatorname{tg} \phi
$$

$\mathrm{T}=$ kuat geser tanah $(\mathrm{kN} / \mathrm{m} 2)$

$\sigma=$ tegangan normal pada bidang runtuh $(\mathrm{kN} / \mathrm{m} 2)$

$\mathrm{c}=$ kohesi tanah $(\mathrm{kN} / \mathrm{m} 2)$

$\phi=$ sudut gesek dalam tanah (derajad)

Pendistribusian nilai kuat geser batuan digunakan metode Kriging, Awali, 2013, mengatakan bahwa kriging merupakan analisis data geostatistik yang digunakan untuk mengestimasi besarnya nilai yang mewakili suatu titik yang tidak tersampel berdasarkan titik-titik sampel yang berada disekitarnya dengan mempertimbangkan korelasi spasial yang ada dalam data tersebut. Kriging merupakan suatu metode interpolasi yang menghasilkan prediksi atau estimasi tak bias dan memiliki kesalahan minimum.

\section{HASIL PENELITIAN DAN PEMBAHASAN}

\section{Hasil Penelitian}

Daerah penelitian secara geologi termasuk ke dalam Formasi Muaraenim. Batuan penyusun daerah penelitian terdiri dari perselingan batulempung, batupasir, lapisan batubara dan endapan volkanik, serta lapisan batubara tebal sampai 10 meter lebih. Fosil kayu diketemukan dalam lapisan batupasir tufaan, yang masih kelihatan struktur kayunya dan telah tersilisifikasi. Struktur sedimen yang dijumpai adalah cross bedding, ripple cross stratification, scour and fill dan lensa-lensa lempung. Penyebaran batuan secara horizontal berdasarkan interpretasi dari data Geophysical Log dan pemetaan geologi permukaan menunjukkan bahwa di daerah penelitian lapisan batuan mempunyai arah $\mathrm{N} 350^{\circ} \mathrm{E} / 20^{\circ}-40^{\circ}$.

Struktur geologi yang berkembang di daerah penelitian adalah arah perlapisan batuan dan patahan, pada umumnya patahan yang dijumpai adalah patahan sekunder yang berjenis patahan naik berarah baratlaut dan patahan geser dengan arah timutlaut, pada umumnya mempunyai arah sekitar $\mathrm{N} 230^{\circ} \mathrm{E} / 20^{\circ} 40^{\circ}$.

Interpretasi dan analisis didasarkan pada data core yang diambil dari 45 lubang bor dengan kedalaman 40 meter s.d. 100 meter, data yang diambil untuk analisis laboratorium adalah core dari 3 lubang bor dengan kedalaman tertentu untuk dianalisis sifat fisik dan mekaniknya dan data geophysical logging untuk analisis korelasi diambil dari seluruh lubang bor. 


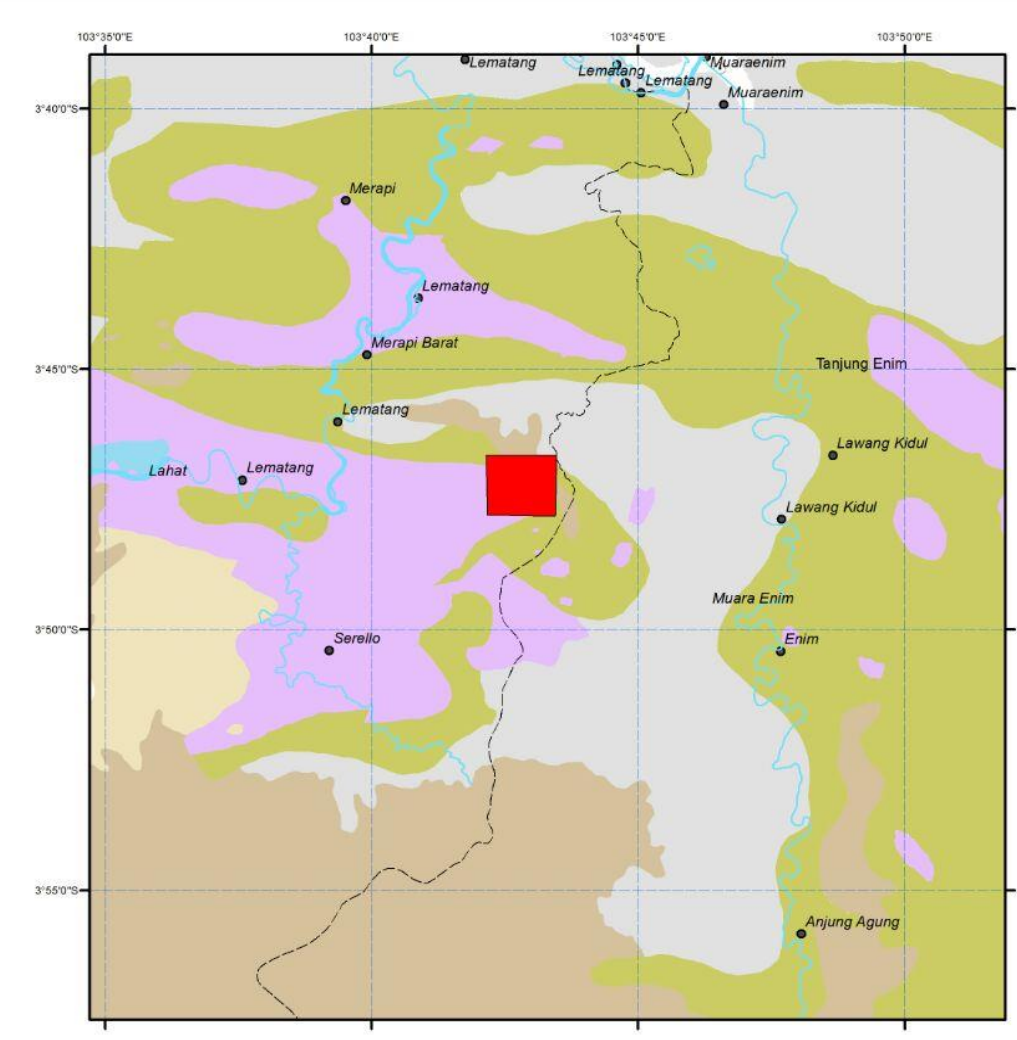

PETA GEOLOGI DAERAH LAHAT PROVINSI SUMATERA SELATAN

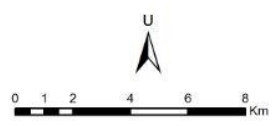

\section{KETERANGAN}

- Sungai

Daerah Penelitian

L _._. Batas Kabupaten

Litologi

Aluvium

Andesit

Breksi Gunungapi - Tu

Formasi Air Benakat

Formasi Gumai

Formasi Kasai

Formasi Muara Enim

Satuan Gunungapi Muda

Gambar 2. Peta Geologi lembar Lahat, Provinsi Sumatera Selatan (Gafoer S, Cobrie T, Purnomo J, 1986)

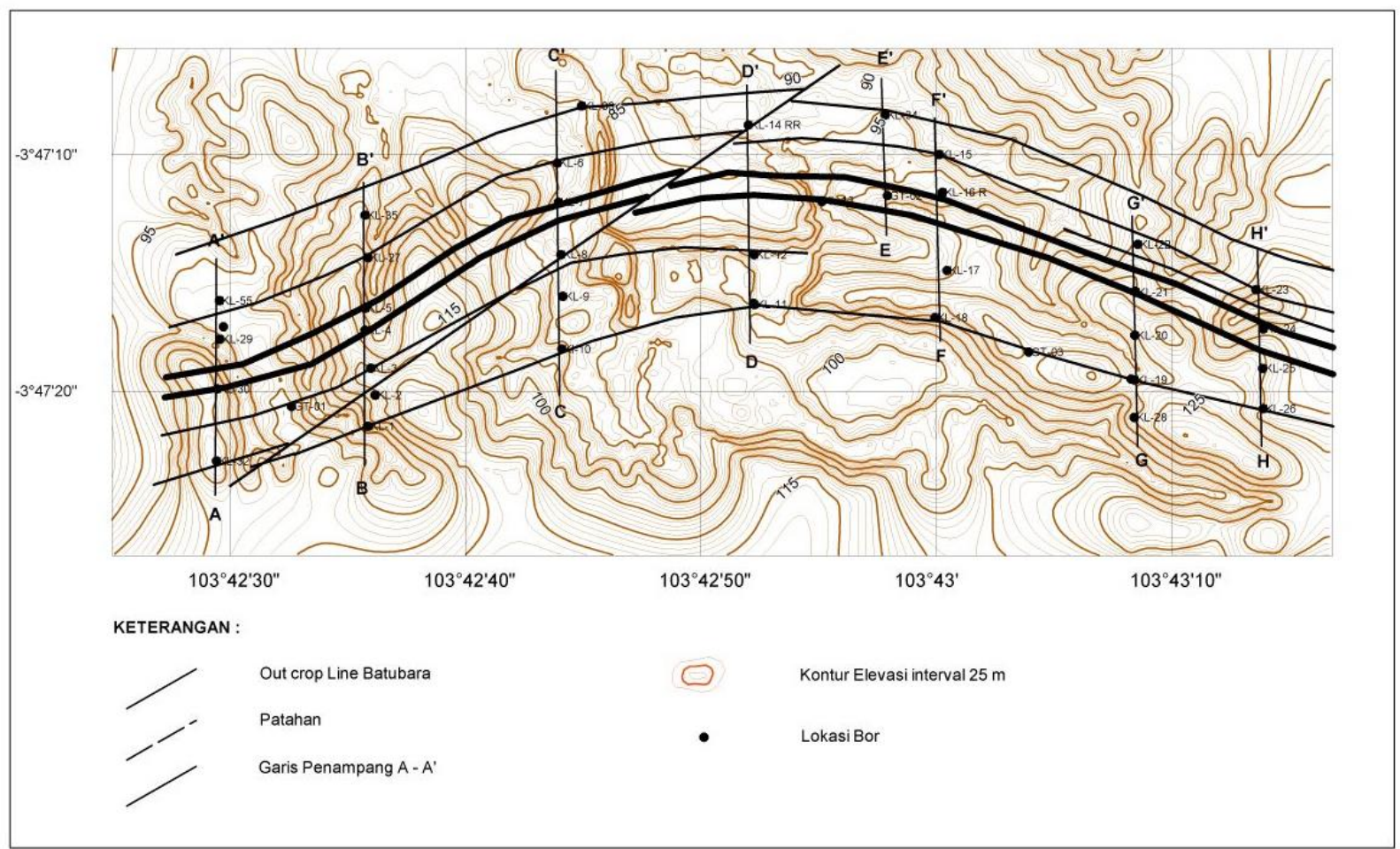

Gambar 3. Lokasi bor dan penyebaran batubara di daerah penelitian (PT. Mintek Demindo 2013, tidak dipublikasikan) 


\section{MAKALAH ILMIAH}

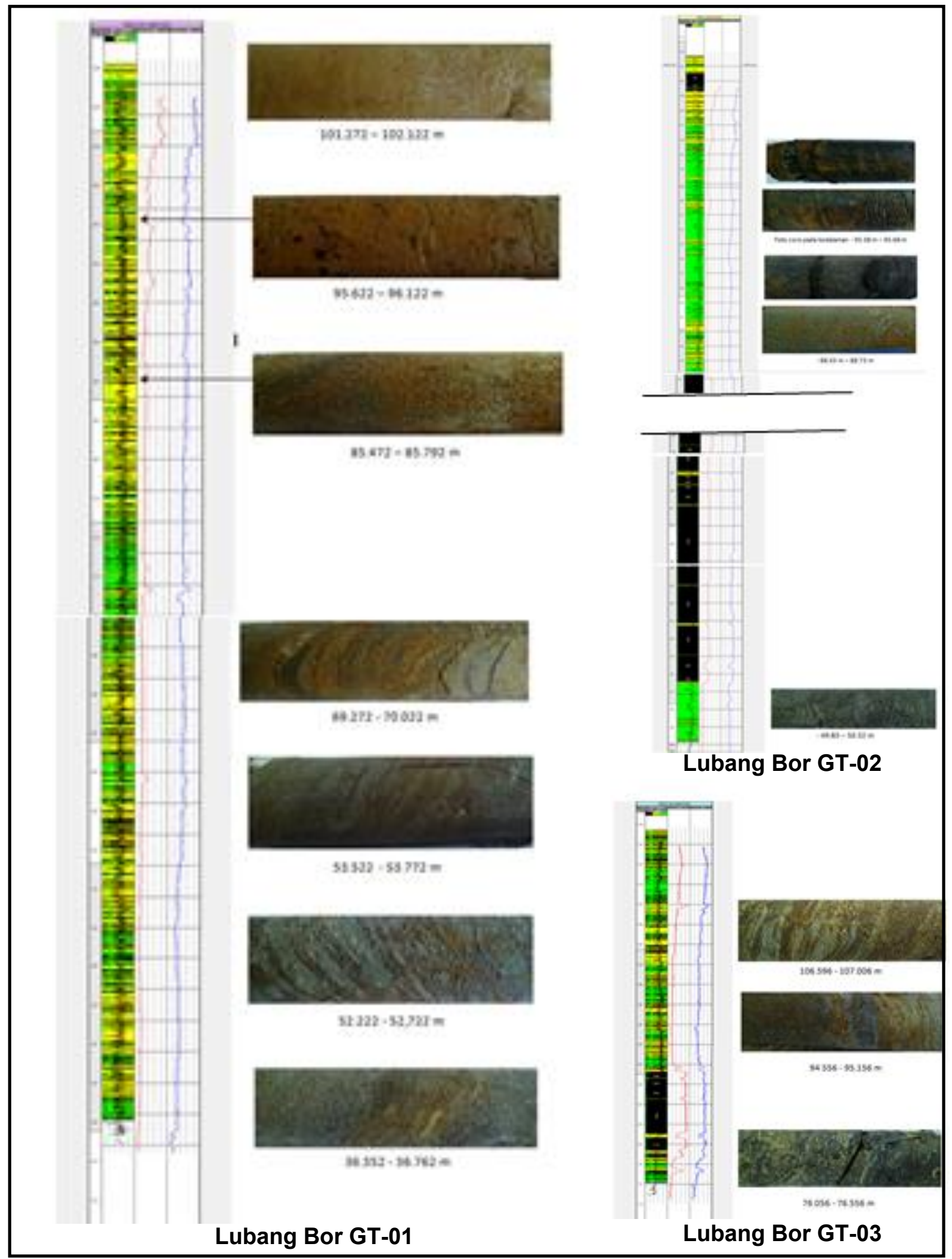

Gambar 4. Lokasi pengambilan sampel dan core yang dianalisis 


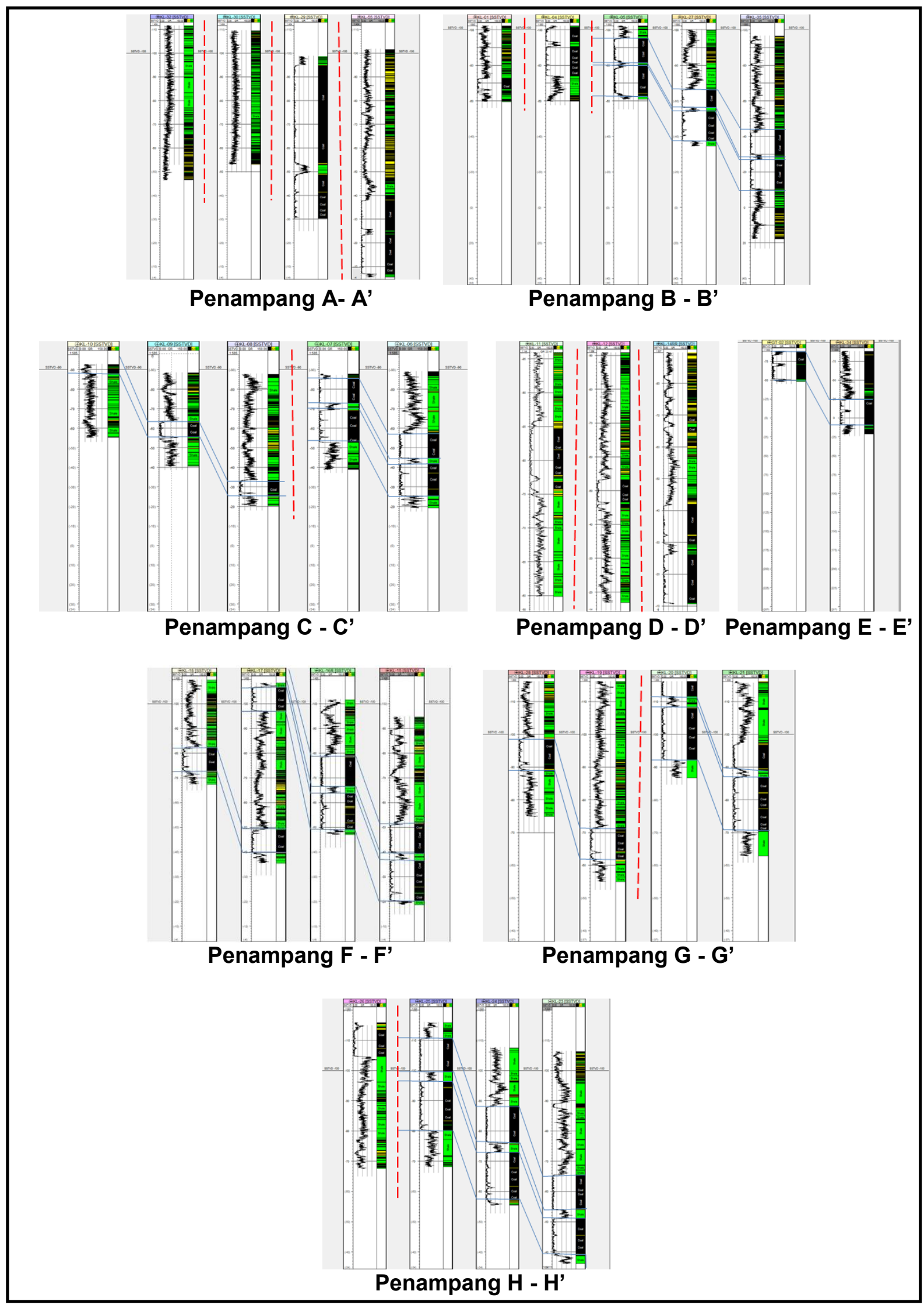

Gambar 5. Penampang stratigrafi berdasarkan gama ray 


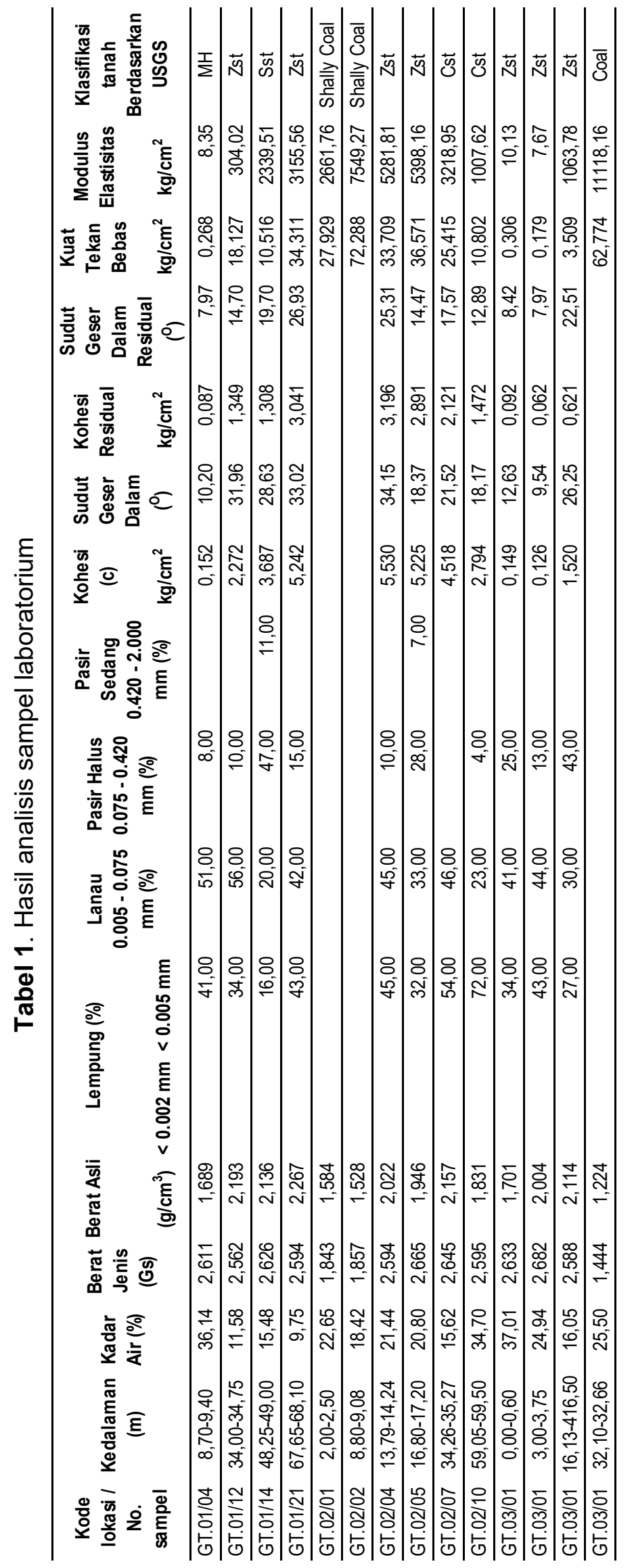




\section{MAKALAH ILMIAH}

Tabel 2. Penamaan batuan sedimen berdasarkan besar butir berdasarkan klasifikasi ASSHTO

\begin{tabular}{ccccc}
\hline Nama Golongan & \multicolumn{4}{c}{ Ukuran Butir (mm) } \\
\cline { 2 - 5 } & Kerikil & Pasir & Lanau & Lempung \\
\hline $\begin{array}{c}\text { American Association of State Highway and } \\
\text { Transportation Official (ASSHTO) }\end{array}$ & $76,2-2$ & $2-0,075$ & $0,07-0,002$ & $<0,002$ \\
\hline
\end{tabular}

Tabel 3. Tabel penolong untuk menghitung korelasi antara besar butir dan sudut geser dalam $(\varnothing)$

\begin{tabular}{|c|c|c|c|c|c|c|c|c|}
\hline \multirow{2}{*}{ No } & \multirow{2}{*}{ besar butir } & \multirow{2}{*}{$\varnothing$} & (X-X & \multicolumn{2}{|c|}{ (Y-Y rata2) } & \multirow[b]{2}{*}{$\mathbf{Y}^{2}$} & \multirow[b]{2}{*}{$\mathbf{X Y}$} & \multirow[b]{2}{*}{$x^{2} y^{2}$} \\
\hline & & & $\mathbf{X}$ & $\mathbf{Y}$ & $\mathrm{X}^{2}$ & & & \\
\hline 1 & 0,075 & 10,20 & $-0,058$ & $\begin{array}{l}-12,02 \\
\end{array}$ & 0,003385 & 144,5241 & 0,699451 & 0,489232 \\
\hline 2 & 0,075 & 31,96 & $-0,058$ & 9,74 & 0,003385 & 94,83219 & $-0,56659$ & 0,321019 \\
\hline 3 & 0,420 & 28,63 & 0,287 & 6,41 & 0,082265 & 41,06479 & 1,837983 & 3,378182 \\
\hline 4 & 0,075 & 33,02 & $-0,058$ & 10,80 & 0,003385 & 116,6007 & $-0,62826$ & 0,394708 \\
\hline 5 & 0,075 & 34,15 & $-1,390$ & 11,93 & 1,9321 & 142,2815 & $-16,5802$ & 274,9021 \\
\hline 6 & 0,075 & 18,37 & $-0,058$ & $-3,85$ & 0,003385 & 14,8365 & 0,224106 & 0,050223 \\
\hline 7 & 0,050 & 21,52 & $-0,083$ & $-0,70$ & 0,006919 & 0,492549 & 0,058379 & 0,003408 \\
\hline 8 & 0,050 & 18,17 & $-0,083$ & $-4,05$ & 0,006919 & 16,41723 & 0,337038 & 0,113594 \\
\hline 9 & 0,075 & 12,63 & $-0,058$ & $-9,59$ & 0,003385 & 92,00298 & 0,558069 & 0,311441 \\
\hline 10 & 0,075 & 9,54 & $-0,058$ & $-12,68$ & 0,003385 & 160,8285 & 0,737851 & 0,544424 \\
\hline \multirow[t]{3}{*}{11} & 0,420 & 26,25 & 0,287 & 4,03 & 0,082265 & 16,22625 & 1,155356 & 1,334847 \\
\hline & 1,465 & 244,440 & $-1,332$ & 0,000 & 2,131 & 840,107 & $-12,167$ & 281,843 \\
\hline & 81818 & 22,22182 & & & & & & \\
\hline
\end{tabular}

\section{PEMBAHASAN}

\section{Hubungan Batuan Dengan Sudut Geser Dalam}

Penamaan batuan dalam penelitian ini

diigunakan ukuran besar butir dari ASSHTO seperti dalam tabel di bawah ini dan hasil laboratorium dapat dilihat pada tabel 1 di atas. Hubungan antara batuan dengan kuat geser batuan digunakan uji korelasi.

$$
\begin{aligned}
r & =\frac{\sum x y-\frac{\sum x \sum y}{n}}{\sqrt{\left[\sum x^{2}-\frac{\left(\sum x\right)^{2}}{n}\right]\left[\sum y^{2}-\frac{\left(\sum y\right)^{2}}{n}\right]}} \\
& =\frac{3,381}{253,300} \\
& =0,013
\end{aligned}
$$

$$
\begin{aligned}
t_{\text {hit }} & =\frac{r \sqrt{(n-2)}}{\sqrt{1-r^{2}}} \\
& =\frac{0,040}{0,9999} \\
& =0,040
\end{aligned}
$$

Kesimpulan $t_{\text {hit }} 0,040<t_{\text {tab }} 1,833$ hal ini berarti bahwa besar butir (jenis batuan) dan sudut geser dalam ( $\varnothing)$ tidak ada hubungan korelasi.

\section{Penyebaran Kuat Geser Batuan Pada Daerah Penelitian}

Kuat geser batuan adalah merupakan indek kualitas batuan, semakin kecil kuat batuan akan semakin lemah kekuatan batuan dalam menyangga beban dan menjadi bidang lemah. Dalam penambangan dengan metoda tambang 
terbuka, bidang lemah ini akan sangat berpengaruh terhadap sudut lereng penambangan. Perhitungan kuat geser batuan dengan rumus kuat geser batuan dari Mohr: $\mathrm{T}=\mathrm{c}+\sigma \tan \varnothing$, dimana semakin kecil nilai kuat geser, maka akan semakin lemah kekuatan batuannya.

Dalam penambangan batubara nilai kuat geser batuan sangat berpengaruh dalam pembuatan sudut kemiringan lereng tambang, dimana dalam hal ini dapat diterapkan dalam optimasi penambangannya, alat bongkar, muat dan angkut yang digunakan dimensinya dapat disesuaikan dengan nilai kuat geser batuan dan cadangan yang ada sehingga pengambilan batubaranya dapat optimum. Data dalam penelitian terdiri dari 32 lubang bor dengan kedalaman beragam antara 27 meter s.d. 120 meter dari permukaan. Untuk dapat menggambarkan penyebaran kuat geser batuan digunakan metode Kriging dan untuk dapat melihat penggambaran penyebaran secara vertikal, daerah penelitian dibagi menjadi empat elevasi dengan perbedaan setiap elevasi adalah 20 meter.

\section{Penyebaran Kuat Geser Batuan Pada Elevasi Permukaan}

Penyebaran kuat geser pada elevasi permukaan data yang digunakan adalah data kuat geser yang dihitung rata-rata dari permukaan sampai kedalaman 20 meter di bawah permukaan.

Penyebaran kuat geser batuan dihitung dengan menggunakan metode ordinary kriging, block estimation, dengan weight model gaussian, arah $\mathrm{N} 360^{\circ} \mathrm{E}$, lebar 20 meter.

\section{Penyebaran Kuat Geser Batuan Pada Elevasi 20 Meter Di bawah Permukaan}

Penyebaran kuat geser pada elevasi 20 meter di bawah permukaan permukaan ini data yang digunakan adalah data kuat geser yang dihitung rata-rata dari 20 meter di bawah permukaan sampai kedalaman 40 meter di bawah permukaan.

\section{Penyebaran Kuat Geser Batuan Pada Elevasi $\mathbf{4 0}$ Meter Di bawah Permukaan}

Penyebaran kuat geser pada elevasi 40 meter di bawah permukaan permukaan ini data yang digunakan adalah data kuat geser yang dihitung rata-rata dari 40 meter di bawah permukaan sampai kedalaman 60 meter di bawah permukaan.

\section{Penyebaran Kuat Geser Batuan pada Elevasi 60 Meter di Bawah Permukaan}

Penyebaran kuat geser pada elevasi 60 meter di bawah permukaan permukaan ini data yang digunakan adalah data kuat geser yang dihitung rata-rata dari 60 meter di bawah permukaan sampai kedalaman akhir lubang bor di bawah permukaan.

\section{Penggambaran Penyebaran Kuat Geser Batuan Secara Vertikal}

Penggambaran secara vertikal ini dimaksudkan untuk dapat memperlihatkan kemenerusan kuat geser batuan secara vertikal, dari penggambaran secara vertikal ini dapat memperlihatkan apakah suatu zona batuan lemah membesar atau melebar di bawah permukaan, sehingga dapat untuk memprediksi kemungkinan besar sudut lereng yang akan dibuat pada waktu penambangan sudah mencapai pada elevasi-elevasi tertentu. 


\section{MAKALAH ILMIAH}

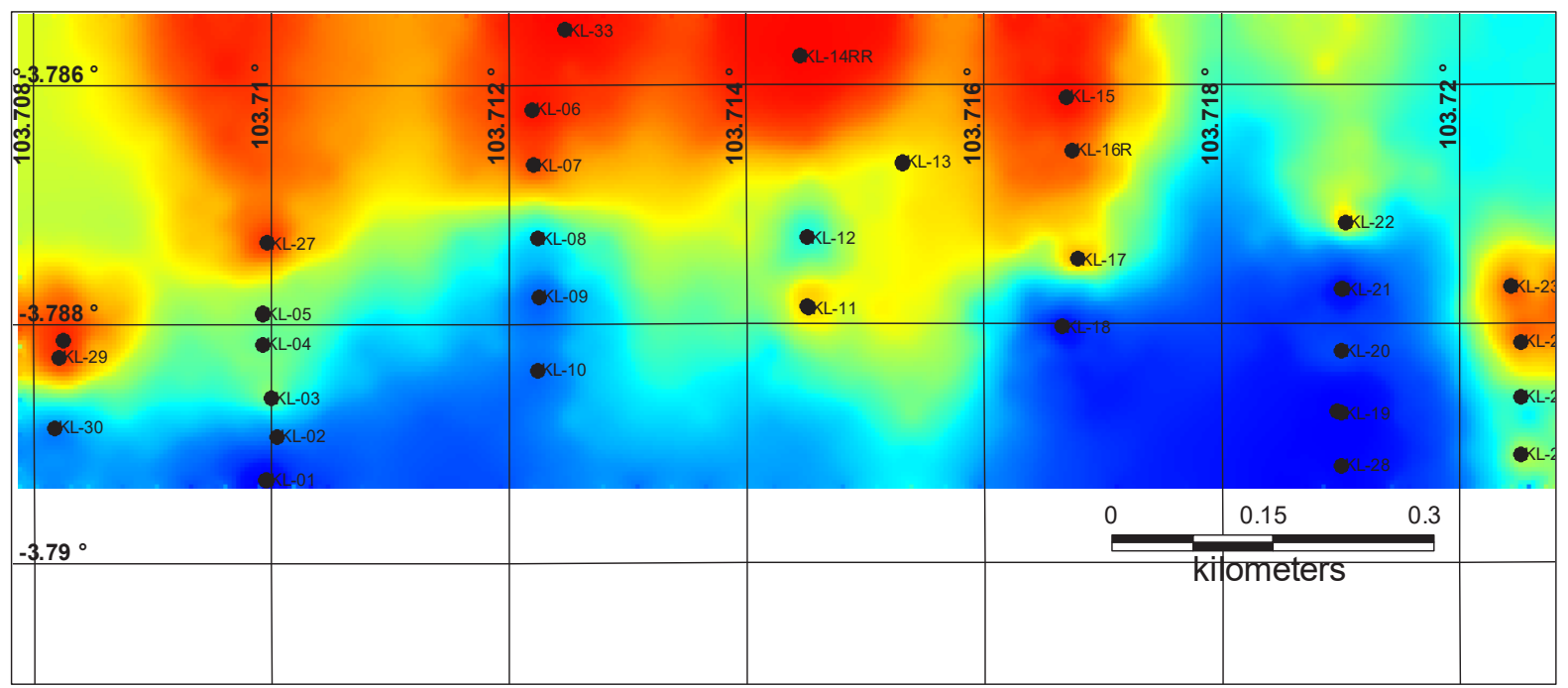

\section{KETERANGAN}

$<200$ ton/m2 RENDAH SEKALI

$300-400$ ton $/ \mathrm{m} 2$ MENENGAH

$200-300$ ton/m2 RENDAH

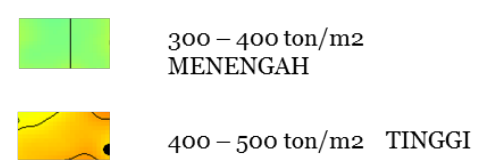

Gambar 6. Penyebaran kuat geser pada elevasi permukaan

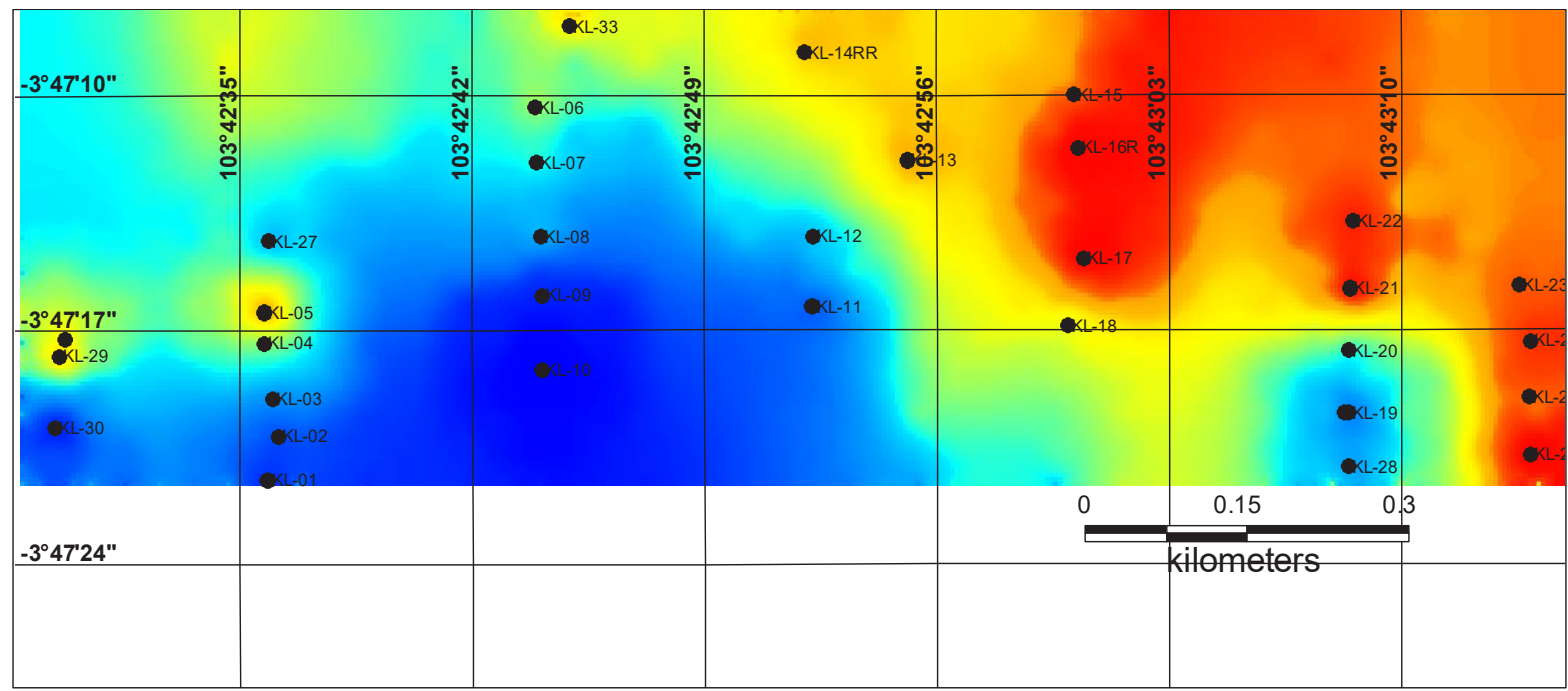

\section{KETERANGAN}

$<200$ ton/m2 RENDAH SEKALI

$300-400$ ton $/ \mathrm{m} 2$ MENENGAH

Gambar 7. Penyebaran kuat geser pada elevasi 20 meter di bawah permukaan 


\section{MAKALAH ILMIAH}

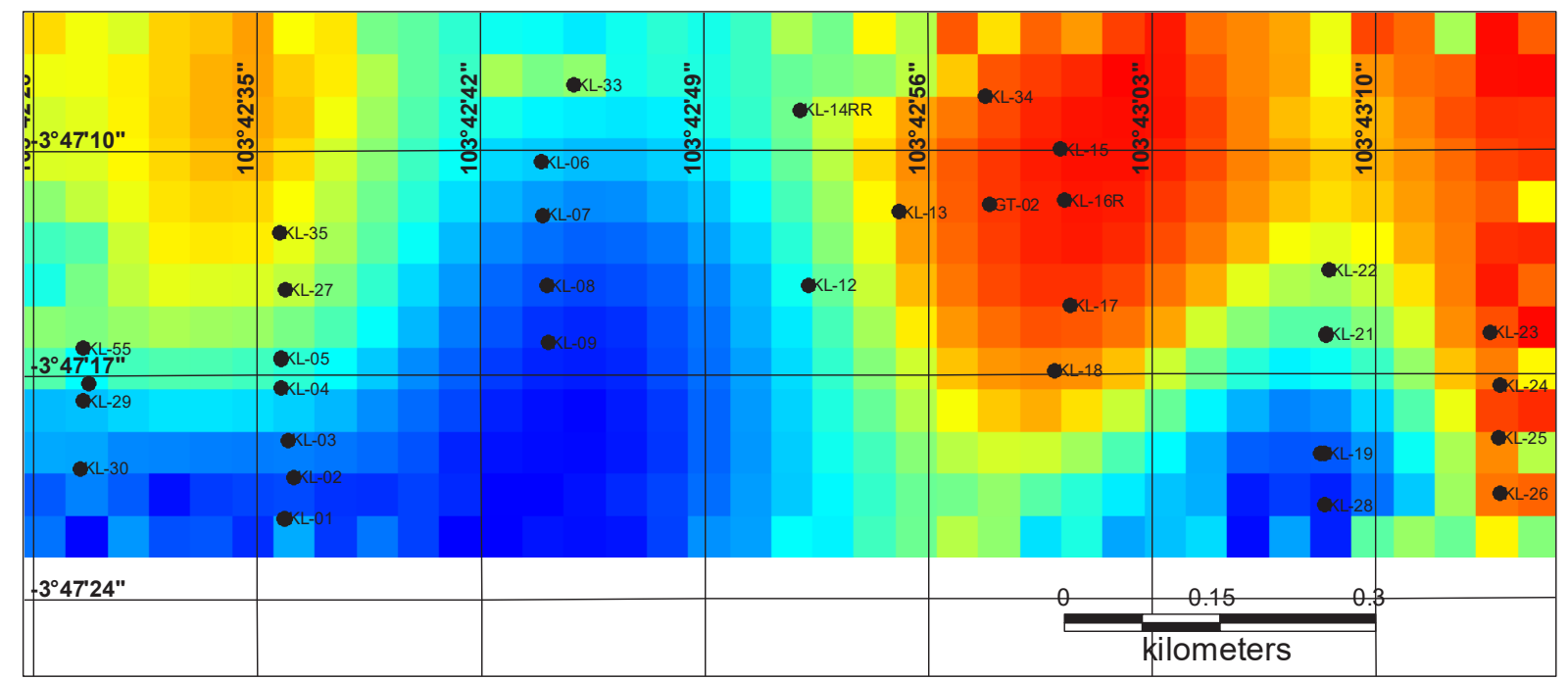

KETERANGAN

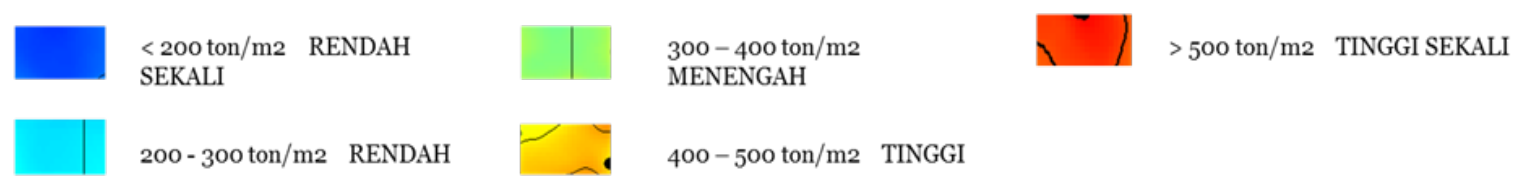

Gambar 8. Penyebaran kuat geser pada elevasi 40 meter di bawah permukaan

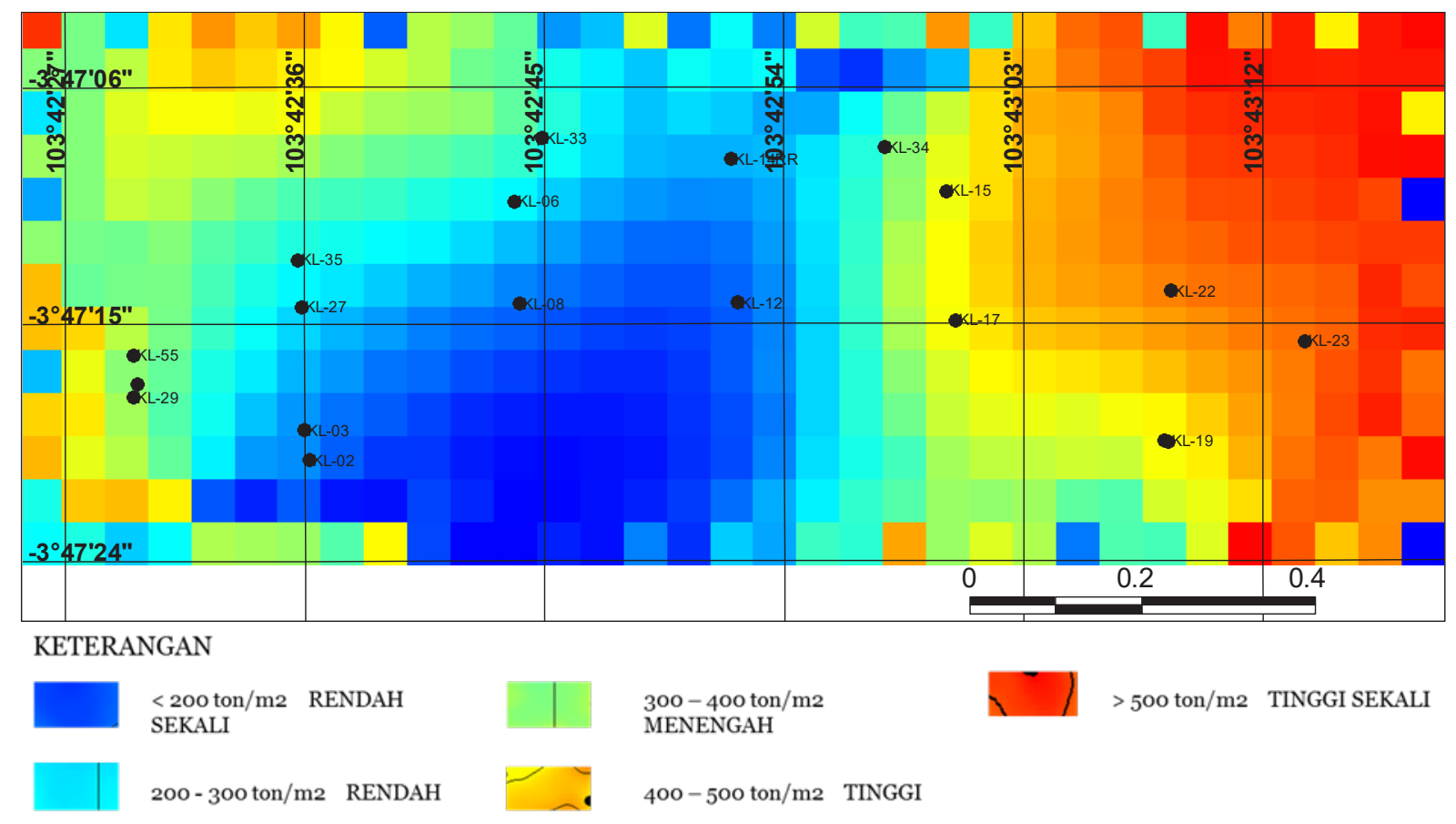

Gambar 9. Penyebaran kuat geser pada elevasi 60 meter di bawah permukaan 


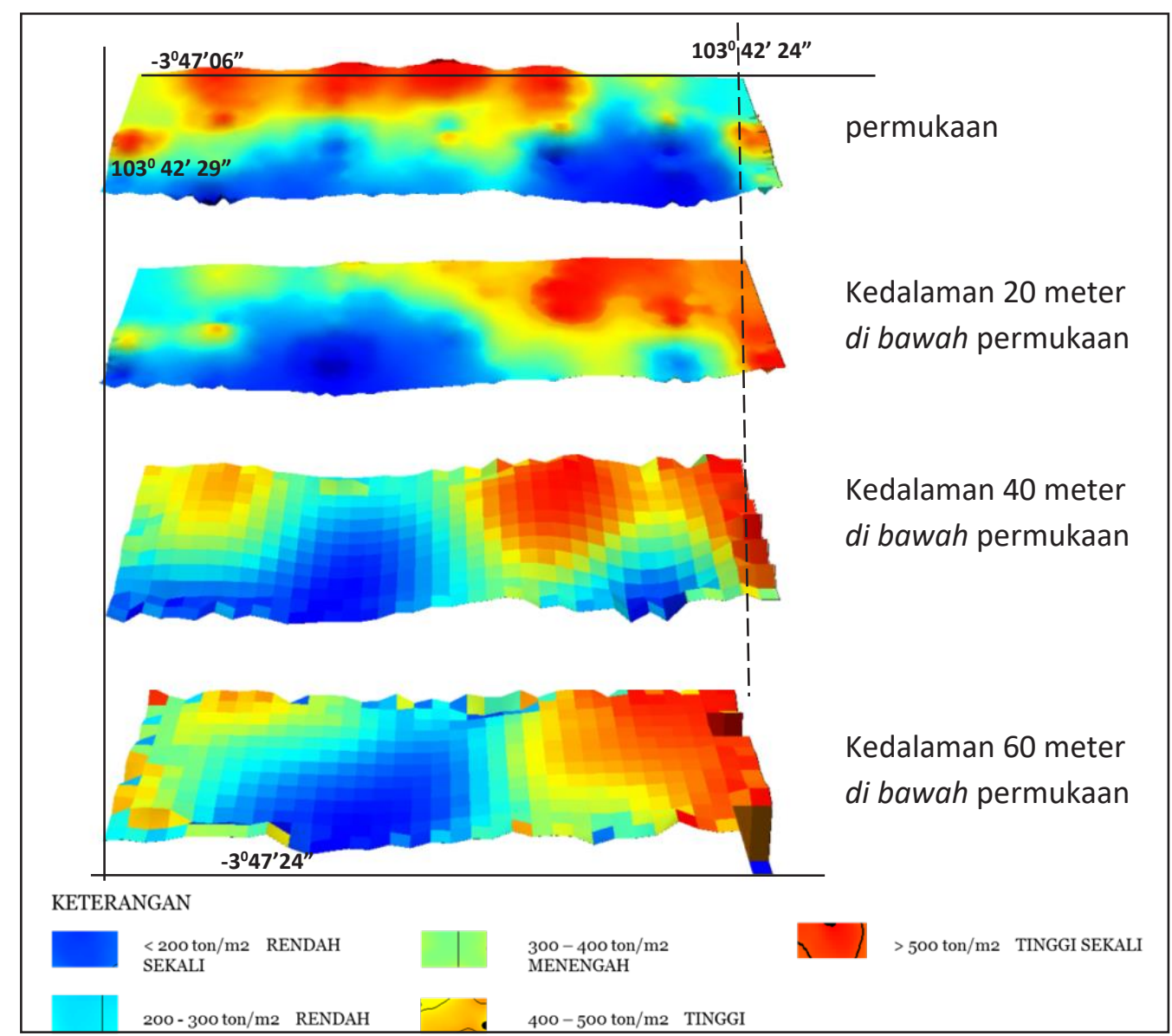

Gambar 10. Penggambaran distribusi kuat geser batuan secara vertikal

Pada Gambar 10 di atas terlihat batuan yang mempunyai kuat geser batuan rendah ( $<200$ ton $/ \mathrm{m}^{2}$ ) (berwarna biru) penyebarannya semakin dalam semakin mengecil.

\section{Hubungan Antara Penyebaran Kuat Geser Batuan dengan Keberadaan Cadangan Batubara}

Stratigrafi daerah penelitian terdiri dari satuan batuan tidak resmi, dari tua ke muda adalah sebagai berikut: satuan batulempung, dan satuan batupasir, dan satuan aluvium di daerah penelitian ini ditemukan lapisan batubara tebal sampai 10 meter lebih, fosil kayu diketemukan dalam lapisan batupasir tufaan, yang masih kelihatan struktur kayunya dan telah tersilisifikasi. Struktur sedimen yang dijumpai adalah cross bedding, ripple cross stratification, scour and fill dan lensa-lensa lempung. Dari data tersebut berdasarkan model Horne, 1978, lingkungan pengendapan daerah ini adalah termasuk dalam transitional lower delta plain.

Dari hal tersebut di atas dapat dilihat bahwa lapisan batubara berada dalam lapisan batuan yang tidak homogen, dan berdasarkan hasil analisis satuan batuan tidak berkorelasi dengan kuat geser batuan, Jadi untuk dapat mengoptimalkan pengambilan batubara harus diperhatikan kedudukan cadangan batubaranya dengan zona kuat geser batuan yang ada untuk mendapatkan sudut lereng yang optimum.

\section{KESIMPULAN}

Dari analisis dengan menggunakan metode Kriging diketahui kuat geser batuan yang mempunyai nilai rendah (200 ton $/ \mathrm{m}^{2}$ ) pada permukaan mempunyai penyebaran di selatan daerah penelitian, dilihat secara vertikal penyebaran kuat geser batuan yang mempunyai nilai rendah terlihat mengarah ke barat-selatan 
dan menerus hingga kedalaman -60 meter di bawah permukaan.

\section{UCAPAN TERIMA KASIH}

Penulis mengucapkan banyak terima kasih kepada tim editor yang telah membantu dalam penyempurnaan makalah dan kepada dewan redaksi atas dimuatnya makalah dalam buletin ini.

\section{DAFTAR PUSTAKA}

Anonim, 2016. Neraca sumber daya dan cadangan batubara di Indonesia, Pusat Sumber Daya Mineral Batubara dan Panas Bumi.

Awal, A.A., Yasin, H., Rahmawati, R., 2013, Estimasi Kandungan Hasil Tambang Menggunakan Ordinary Indikator Kriging, JURNAL GAUSSIAN, Volume 2, Nomor 1.

Azizi, A.A., 2011, Karakterisasi Parameter Masukan untuk Analisis Kesetabilan lereng tunggal (Studi kasus di PT. Tambang Batubara Bukit Asam TBK, Tanjung Enim, Sumatera Selatan), Prosiding Seminar Nasional AVoER ke-3 Palembang, 26-27 Oktober 2011.

Bassiouni, Z., 1994. Theory Measurement and interpretation of Well Logs. Texas. USA.

Boggs, S., 2006. Principle of Sedimentology and Stratigraphy Fourth Edition. New Jersey: Merril Publishing.

De Coaster, 1974, The Geology of the Central and South Sumatera Basin, Proceeding Indonesia Petroleum Association - 3rd Annual Convention.

Dewan, J.T., 1983. Essentials of Modern Open Hole Log Interpretastion. Tulsa, Oklahoma: Pennwell Corp.
Dipatunggoro, G., dan Zakaria, Z., 2012, Kajian geoteknik terhadap formasi Tanjung di Pit Sayuna, Satui, Kalimantan Selatan, dengan menggunakan metode Slope Mass Rating, Buletin of Scientific Contribution, Volume 10, Nomor 2, Agustus 2012.

Doveton, J.H., 1986. Log Analysis of Subsurface Geology. USA: John Wiley and Sons, Inc.

Gafur, S., 1986, Peta Geologi Lembar Lahat, peta geologi regional bersistem skala $1: 250.000$, Pusat Penelitian dan Pengembangan Geologi (P3G) Bandung.

Munadi, S., 2005, Pengantar Geostatistik, Universitas Indonesia, Jakarta.

Nichols, G., 2009. Sedimentology and Stratigraphy. United Kingdom: Balckwell.

Pangemanan, V.G.M., Turangan A.E, Sompie O.B.A, 2014, Analisis kesetabilan lereng dengan metode Fellenius (Studi Kasus: Kawasan Citraland), Jurnal Sipil Statik Vol.2 No.1, Januari 2014.

Sagala, P.S.S., 2014, Studi Pengaruh Penambahan Tanah Lempung A-7 Terhadap Kuat Geser Tanah Pasir Sungai, Jurnal Teknik Sipil dan Lingkungan, Vol.2, No.2, Juni 2014.

Selley, R.C., 1988. Ancient Sedimentary Environments Third Edition.Cornell University Press, Ithaca, N.Y.

Seru, I., Zakaria, Z., dan Muslim, D., 2015, Orientasi Inti Batuan Hasil Pemboran Pada Rancang Lereng Tambang Emas Terbuka Araren di PT. Tambang Tondano Nusajaya, Sulawesi Utara, buletin Sumber Daya Geologi, Volume 10, No. 3, November 1015.

Shaylendra, Y., 2012, Lingkungan Pengendapan Formasi Talang Akar Pada Lapangan Cekungan Sumatera Selatan Berdasarkan Data Core dan Wireline Log, e-Jurnal Mahasiswa, Vol 1, No 1.

\begin{tabular}{|ll|}
\hline Diterima & $:$ 8 September 2016 \\
Direvisi & $: 10$ Oktober 2016 \\
Disetujui & $: 16$ November 2016
\end{tabular}

